\title{
Designing a solar and wind hybrid system for small-scale irrigation: a case study for Kalangala district in Uganda
}

\author{
Shaffic Ssenyimba, Nicholas Kiggundu *iD and Noble Banadda
}

\begin{abstract}
Background: Dynamics in rainfall patterns are posing a threat to crop production in Uganda. Irrigation can be used to ensure constant production; however, the motorized powered irrigation methods are quite costly to run in addition to being environmentally unsustainable. There is thus need for alternative irrigation methods. Renewable energy sources which are readily available can be used to power irrigation systems. This study hence sought to design an appropriate wind-solar hybrid system for irrigating 1 acre of banana plantation in Kalangala district, Uganda.

Methods: Using metrological data, mean wind speed and monthly solar irradiance of global radiation horizontal for the district were analysed. A wind-solar hybrid system was optimally designed for a standalone drip irrigation system of 450 banana plants on 1-acre land with water requirement of $33.73 \mathrm{~m}^{3} \mathrm{~d}^{-1}$. The wind turbine was simulated to analyse for static pressure, cut plane flow behaviour, turbulence intensity and stress distribution exposed at $20 \mathrm{~m} \mathrm{~s}^{-1}$ wind speed. A cost analysis was done to estimate the total project investment, maintenance and operational cost, annual project gross income, net income stream and the annual net real rate of returns.

Results and conclusions: The simulation results showed that the system could effectively operate at speeds of $20 \mathrm{~m}$ $\mathrm{s}^{-1}$ without deformation. The net present value of income stream for the first 5 years at $r=5 \%$ was $12,935,468$ UGX with a net real rate of return of $3.5 \%$ per year. The study will, therefore, be a useful guideline in making investment decisions in hybrids irrigation systems.
\end{abstract}

Keywords: Cost analysis, Irrigation, Kalangala district, Wind-solar hybrid, Simulation, SolidWorks, Vertical axis wind turbine

\section{Background}

Over $78 \%$ of Uganda's population engage in agriculture [1] hence making it a backbone of the country's economy. However, climate change/variability has continued to affect crop and livestock production making these economic ventures unreliable. Irrigation has the potential to solve problems of water and food security arising from climate change impacts [2]. However, irrigation requires both energy and water to operate. Water and energy are two interdependent sectors with a predicted $40 \%$ increase in energy demand leading to a $30 \%$ increase in water demand [3]. These high energy demands hence make irrigation adoption limited economically especially to the majority of smallholder farmers who earn less than a

* Correspondence: kiggundu@caes.mak.ac.ug

Department of Agricultural \& Biosystems Engineering, Makerere University, Kampala, Uganda dollar per day. To combat this challenge of over-reliance on the conventional grid and motorized pumps for irrigation, renewable energy irrigation pumps are gaining importance [4]. There is a growing trend to explore alternative renewable energy sources in Uganda, apart from hydropower, to boost the growing industrial sector. Solar and wind water pumping is a promising alternative to Uganda's convection diesel or petrol and electricity water pumping systems [5]. This is because the country has an equatorial climate characterized with abundant sunshine and moderate wind speeds. Further industrial development will be attributed to reliable and high-quality energy sources and this will constitute a substantial increase in quality of life for Ugandan citizens [6].

Developing and adopting environmentally sound renewable energy technologies will aid in modernizing agriculture and improving the livelihoods of vast Ugandans [5]. However, due to the dynamics of renewable resources, use of 
any particular renewable energy resource system as a standalone may lead to in operation during some time of the day and seasons and unnecessary operational and lifecycle costs, as well as components oversizing. These limitations can be overcome by combining two or more renewable energy resources in the form of a hybrid system [7], such as a photovoltaic system and a wind turbine [2]. A hybrid system has the advantage of improved reliability and gives better energy service when compared to a standalone supply system $[2,7]$. Designing renewable energy hybrid systems involves sizing and selecting the best components to provide affordable, efficient and effective renewable energy [2].

Hybrid systems utilizing wind and solar energy have been designed for irrigation systems [2, 4], rural electrification [7] and wastewater treatment [8], and they have proved to be cost-effective and efficient. The population of Kalangala district was estimated at 54,293 people in 2014 growing at 3\% per year [9]. The biggest part of Kalangala district is un-electrified due to its isolated location on an island and low economy, but presents it with an opportunity to use renewable energy technologies. Extension of utility grid lines to most remote and non-electrified areas experiences problems like; high capital investment, high lead time, low load factor, poor voltage regulation, and frequent power supply interruptions [10]. Therefore, a hybrid power system that is costeffective, none polluting and reliable was proposed to mitigate the scarcity of electricity for crop irrigation in Kalangala district. However, there is scanty scientific information on the utilization of solar-wind hybrid systems to meet irrigation energy requirement in Uganda. Thus, the main objective of this study was to access the potential and viability of a wind-solar hybrid drip irrigation system using Kalangala district as a case study.

\section{Methods}

Kalangala district headquarters are located at a latitude 0.32 and 32.29 longitude [11]. The district has a perimeter of $387 \mathrm{~km}$ with a total area of $9066.8 \mathrm{~km}^{2}$ of which water covers $95 \%$. Majority of the population is involved in clustered fishing along the shores of Lake Victoria. The district can only be accessed by ferries which were provided by the Ugandan government and local boats, as there are no bridges linking the islands to the mainland. Fishing, tourism and palm oil production by BIDCO oil refinery (U) Limited are the main revenue generators of the district. Although the district has got good climate conditions, some crops are greatly affected during the prolonged drought from the month of January to March, thus the need for irrigation to maintain a constant flow of water to crops throughout the year.

\section{Data analysis}

Okou [11] analysed Kalangala district solar and wind data of 4 years obtained from the metrological station of National Agricultural crop Resource Research Institute (NACRRI). In his analysis, he obtained the highest average wind speed over the 4 years which was $2.2 \mathrm{~m} \mathrm{~s}^{-2}$ at $10 \mathrm{~m}$. The months of February to April and June to July registered the highest wind speeds ranging from $3.22 \mathrm{~m} \mathrm{~s}^{-2}$ to $8 \mathrm{~m} \mathrm{~s}^{-2}$. December to January registered the lowest wind speeds of $0.4 \mathrm{~m} \mathrm{~s}^{-2}$ to $0.9 \mathrm{~m} \mathrm{~s}^{-2}$. He also stated that "the wind speed was highest from 9:00 am to 6:00 pm due to the prevalent south-east (SE) wind and lowest at night and early morning from 12:00 am to 8:00 am due to the dominant west-south-west (WSW) wind". From his findings, the average solar flux was $167.49 \mathrm{~W} \mathrm{~m}^{-2}$ averaged over the 4 years. He stated that the solar irradiance of Kalangala was greatest between 11:00 am to $3: 00 \mathrm{pm}$ although the area received radiation for $11 \mathrm{~h}$ (from $7 \mathrm{am}$ to $6 \mathrm{pm}$ ) with an average solar flux of over $300 \mathrm{~W} \mathrm{~m}^{-2}$ solar radiation per day. In this study, Kalangala metrological data for a period of 8 years 2010 to 2018 at a height of $10 \mathrm{~m}$ was obtained from [12] and analysed. From the analysis, 2010 and 2018 recorded the highest wind speeds (Fig. 1). The wind speed was highest in the months of July and August at $11.95 \mathrm{~m} \mathrm{~s}^{-1}$ and $10.12 \mathrm{~m} \mathrm{~s}^{-1}$ respectively for the year 2010 and at $11.53 \mathrm{~m} \mathrm{~s}^{-1}$ and $11.24 \mathrm{~m} \mathrm{~s}^{-1}$ for the months of October and July respectively in the year 2018 [12]. The highest wind speed was from 10:00 am in the morning to $5: 00 \mathrm{pm}$ in the evening. The wind speed reduced at night and early morning. According to weather Spark [13], the average hourly wind direction in Kalangala district varies throughout the year and is from the south for 7.2 months January 28 to September 3, with a peak percentage of $79 \%$ on July 3 . Figure 1 shows the average annual Kalangala district wind speed of 8 years.

From Fig. 1, the highest mean speed was in the year 2018 at $5.27 \mathrm{~m} \mathrm{~s}^{-1}$. This was, therefore, used as the wind design parameter for this study. Figures 2 and 3 show Uganda's global horizontal Irradiation and Kalangala district annual average solar irradiation for 8 years from 2010 to 2018 respectively. It is noted that the highest mean annual solar irradiation from 2010 to 2018 was $10.03 \mathrm{kWh}$ recorded in the year 2013. Therefore, $10.03 \mathrm{kWh}$ became the design parameter for the solar system of this study.

\section{Wind turbines}

Like with windmills, wind turbines take the merit of the wind energy and convert it into another form of energy. In this case study, the wind turbine converts kinetic energy in the wind into electrical energy. Small wind turbines like the one designed for this study are usually selected for local usage [14]. Since the electric energy required for the study was less than $100 \mathrm{~kW}$ 


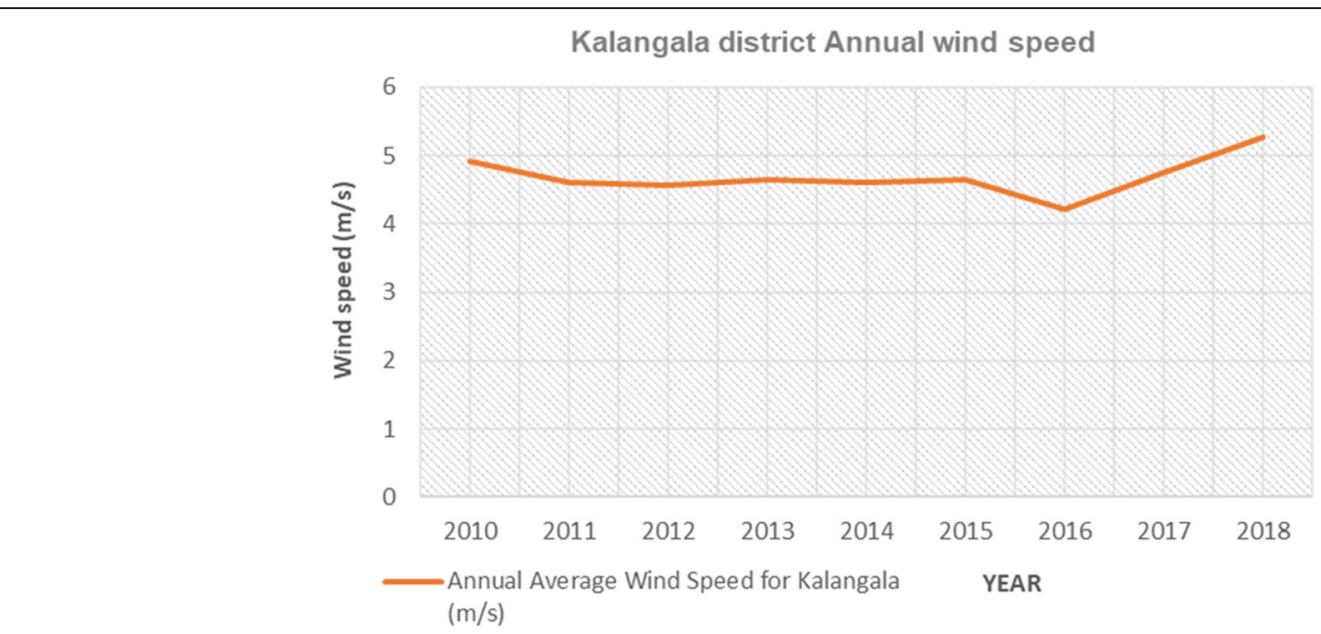

Fig. 1 Annual average Kalangala district wind speed

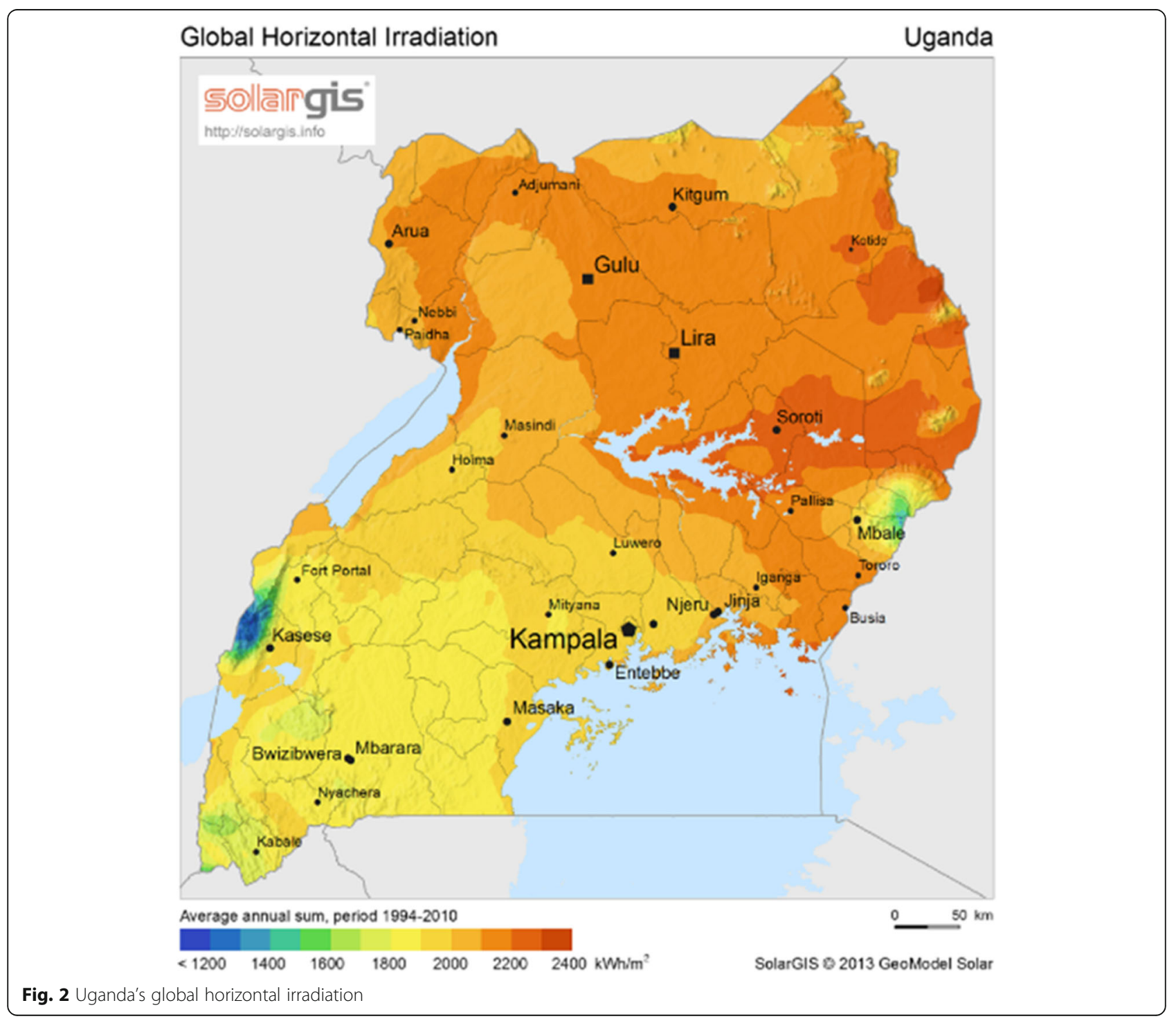




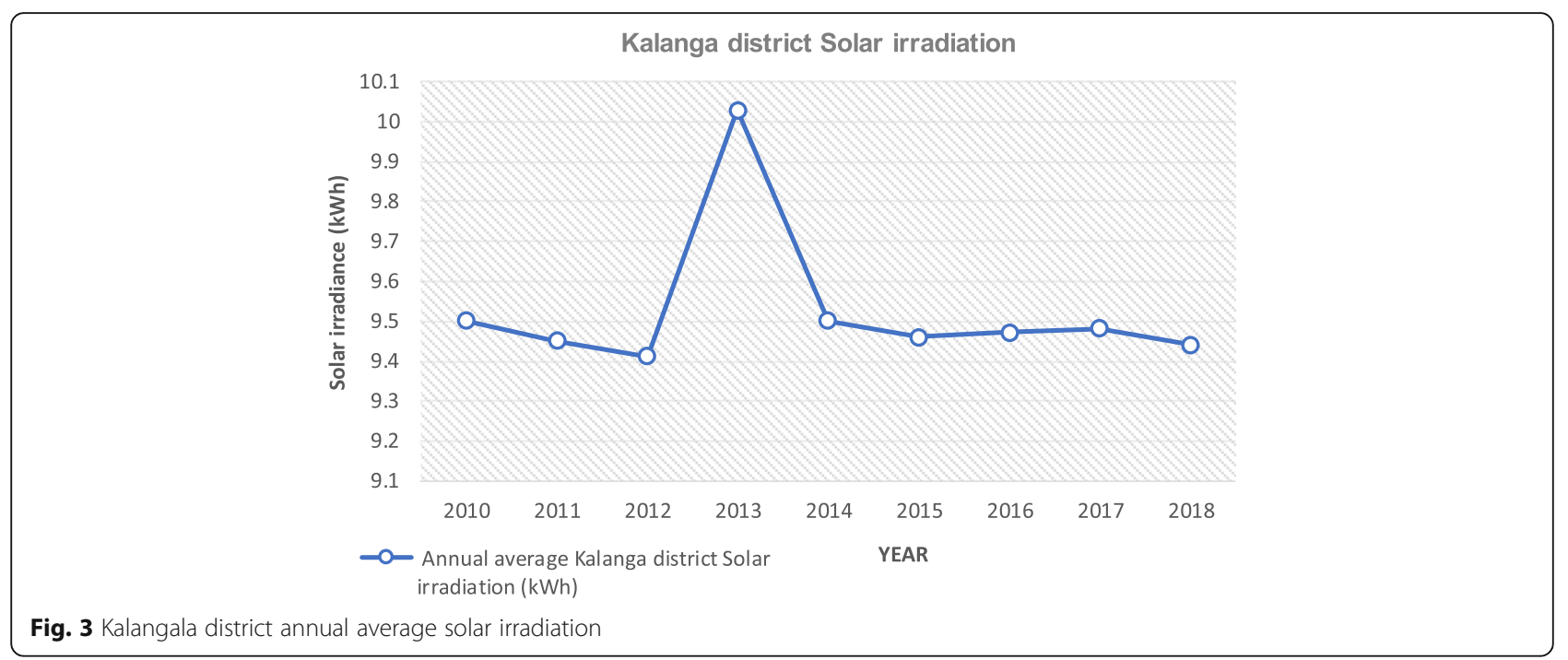

capacity, this became a system constraint, and therefore, the system is categorized as a micro-grid [15]. Micro-grid wind turbines are usually installed in the isolated, off-grid and remote areas where there is no power connected to the national grid as the case for Kalangala district [16]. Johari et al. [14] stated that these days, wind turbine technology is used to power vertical axis wind turbines (VAWT) and horizontal axial wind turbine (HAWT), to light up rural villages, as well as irrigation of crops.

The VAWT was selected for this study, because of the following merits; The VAWT is an omnidirectional and, therefore, can receive wind from all directions, unlike HAWT that is required to face in the direction of wind stream all the time in order to give the required optimum output. Since Kalanga district winds are from all directions, VAWT was considered to be the best option. The VAWT is the best choice to be installed in a more turbulent and slow wind speed environment. It can generally start to produce power at very low wind speeds, unlike the HAWT. "The system for VAWT such as gearbox and other equipment can be packed together and installed closer to the ground, hence eliminating the need for extra cost for maintenance and making it easier to be controlled" [14]. The VAWT is quieter during operation as compared to HAWT. However, VAWT is inefficient in high-speed wind environment due to its low starting torques and issues on its dynamic stability [14].

\section{Designing crop drip irrigation system}

The two main crops grown in Kalangala district are bananas and palm oil. Banana was selected for this study.

\section{Assumptions made}

a. Size of land: one acre $\left(4046 \mathrm{~m}^{2}\right)$ of banana plantation to be irrigated

b. Crop to be irrigated: banana

c. Dripper spacing: $1.524 \mathrm{~m}$

d. Land slope: $0 \%$ land slope

e. The depth of water source: $8 \mathrm{~m}$

f. Water source: well, at the corner of the banana field to be irrigated

\section{Crop water requirement}

In determining the water required for irrigation, the first step was to determine the amount of water that will be needed for the selected crop. Since the need varies during the season, the highest amount that is expected to be used is selected [17]. Crop water requirement varies with crop spacing. Table 1 shows peak water requirements and spacing for commonly grown crops in Africa.

Spacing of banana plants varies with the type of bananas to be planted. "Bogoya" a local variety of banana is widely spaced whereas short ones such as "Nakytengu" banana variety which was considered for this study is closely spaced. For Nakytengu variety, a spacing of $3 \mathrm{~m} \times 3 \mathrm{~m}$ in between the holes gives a banana plant population of 450 per acre and 750 to 900 banana plants per hectare, with a daily water requirement of $25 \mathrm{~L} \mathrm{~d}^{-1}$ [20]. This was the water per meter length of row required, and therefore, the total water required per day for 1 acre of Nakytengu banana plantation was obtained from Eq. 1 [18].

$$
T_{H_{2} \mathrm{O}}=T_{L R}(m) \times R_{H_{2} \mathrm{O}}\left(L m^{-1} d^{-1}\right)
$$

where $T_{\mathrm{H} 20}$ is total water required per day, $T_{\mathrm{LR}}$ the total length of rows and $R_{\mathrm{H} 2 \mathrm{O}}$ is water requirement $\left(\mathrm{L} \mathrm{m}^{-1} \mathrm{~d}^{-1}\right)$. 
Table 1 Peak water requirement for different crops [18]

\begin{tabular}{|c|c|c|c|}
\hline Sr. no. & Crop & $\begin{array}{l}\text { Spacing } \\
(\mathrm{Ft} \times \mathrm{Ft})\end{array}$ & $\begin{array}{l}\text { Peak water requirement } \\
\left(\mathrm{L} \mathrm{d}^{-1} \text { Plant }\right. \\
\end{array}$ \\
\hline \multirow[t]{4}{*}{1} & \multirow[t]{4}{*}{ Grapes } & $6 \times 4$ & $10-12$ \\
\hline & & $8 \times 6$ & $18-20$ \\
\hline & & $8 \times 8$ & 24 \\
\hline & & $8 \times 10$ & 30 \\
\hline \multirow[t]{3}{*}{2} & \multirow[t]{3}{*}{ Pomegranate } & $10 \times 10$ & $30-40$ \\
\hline & & $12 \times 12$ & $40-50$ \\
\hline & & $15 \times 15$ & $70-75$ \\
\hline \multirow[t]{3}{*}{3} & \multirow[t]{3}{*}{ Guava } & $15 \times 15$ & $70-80$ \\
\hline & & $18 \times 18$ & $100-120$ \\
\hline & & $25 \times 25$ & $120-130$ \\
\hline \multirow[t]{2}{*}{4} & \multirow[t]{2}{*}{ Mango } & $25 \times 25$ & $120-140$ \\
\hline & & $30 \times 30$ & $150-170$ \\
\hline \multirow[t]{2}{*}{5} & \multirow[t]{2}{*}{ Sapota/chiku } & $25 \times 25$ & $120-140$ \\
\hline & & $30 \times 30$ & $150-170$ \\
\hline \multirow[t]{2}{*}{6} & \multirow[t]{2}{*}{ Orange/lemon/citrus } & $16 \times 16$ & 75 \\
\hline & & $18 \times 18$ & 85 \\
\hline \multirow[t]{2}{*}{7} & \multirow[t]{2}{*}{ Custard apple } & $10 \times 10$ & 40 \\
\hline & & $12 \times 12$ & 50 \\
\hline \multirow[t]{2}{*}{8} & \multirow[t]{2}{*}{ Ber } & $10 \times 10$ & 30 \\
\hline & & $12 \times 12$ & 55 \\
\hline \multirow[t]{4}{*}{9} & \multirow[t]{4}{*}{ Banana } & $6 \times 4$ & 22 \\
\hline & & $6 \times 6$ & 25 \\
\hline & & $5 \times 5$ & 22 \\
\hline & & $6 \times 5$ & 25 \\
\hline \multirow[t]{2}{*}{10} & \multirow[t]{2}{*}{ Papaya } & $5 \times 4$ & 18 \\
\hline & & $7 \times 7$ & 20 \\
\hline 11 & Coconut & $25 \times 25$ & 90 \\
\hline 12 & Cardamom & $10 \times 10$ & 15 \\
\hline 13 & Rubber & $15 \times 15$ & 24 \\
\hline 14 & Oil palm & $30 \times 23$ & 150 \\
\hline
\end{tabular}

[a] Above water requirements are indicative. Actual water requirements can change according to actual evaporation, soil type and climatic conditions [19]

Given that 1 acre is $4046.7 \mathrm{~m}^{2}$ and considering this area as square that is to say $63.6 \mathrm{~m}$ by $63.6 \mathrm{~m}$, then the total length of rows was obtained through dividing the total area of banana plantation by length of rows [18].

$$
\begin{aligned}
\text { Total length of } \operatorname{rows}\left(T_{L R}\right) & =\frac{63.6 \mathrm{~m} \times 63.6 \mathrm{~m}}{3 \mathrm{~m}} \\
& =1348.32 \mathrm{~m}
\end{aligned}
$$

Water required for the whole field per day was then obtained from Eq. 1.

$$
T_{H_{2} \mathrm{O}}=(1348.32 \times 25)=33,708 L d^{-1}=34 m^{3} d^{-1}
$$

\section{Selection of an in-line drip lateral and irrigation time calculation \\ Assumptions made}

- An inline drip lateral of $16 \mathrm{~mm}$ (pipe size) $\times 2 \mathrm{~L}$

$\mathrm{h}^{-1}(\mathrm{LPH}) \times 0.40 \mathrm{~m}$ (dripper spacing) was selected for the study.

- The irrigation rate for $2 \mathrm{LPH}$ at $0.4 \mathrm{~m}$ lateral is $5 \mathrm{LPH}$.

The peak water requirement is $25 L d^{-1}$.

Therefore, the irrigation time $(h)$ was determined from Eq. 2 [18].

$$
\text { Irrigation time }(h)=\frac{\text { Water requirement }\left(L d^{-1}\right)}{\text { Irrigation rate }\left(L h^{-1}\right)}=\frac{25}{5}=5 h d^{-1}
$$

Therefore, the proposed irrigation system should be operated for $5 \mathrm{~h}$ per section of the field so as to fulfil all water requirements. Since the estimated average availability of the hybrid electricity system is $10 \mathrm{~h} \mathrm{~d}^{-1}$, then the maximum field section required to be irrigated were obtained from Eq. 3 [18].

$$
\begin{aligned}
\text { The maximum field sections required } & =\frac{\text { Electricity availability }(h)}{\text { Irrigation time }(h)} \\
& =\frac{10 h}{5 h}=2 \text { Sections }
\end{aligned}
$$

\section{Determining the lateral total length $\left(L_{L}\right)$}

Total Length $\left(L_{L}\right)$ required by laterals as shown in Eq. 4 is obtained from dividing the total area $\left(\mathrm{m}^{2}\right)$ to be irrigated by minimum row spacing length in meters [21].

$$
L_{L}=\frac{\text { Totalareatobeirrigated }\left(m^{2}\right)}{\text { Rowlength }(m)}=\frac{4046 m^{2}}{3 m}=1349 m
$$

\section{Total discharge required $\left(T_{d s}\right)$}

The total lateral discharge is obtained from Eq. 5 by dividing the product of lateral total length and Emitter flow rate $(\mathrm{GPH})$ of the selected lateral by emitter spacing in meters [21]. 


$$
\begin{aligned}
T_{d s} & =\frac{L_{L \times} \times \text { Emitter flow rate }(\mathrm{LPH})}{\text { Emitter spacing }} \\
T_{d s} & =\frac{1349 \mathrm{~m} \times 2(\mathrm{LPH})}{0.4 m}=6745 \mathrm{LPH}
\end{aligned}
$$

From Table 2, it can be seen that the maximum inline lateral running length for $16 \mathrm{~mm} \times 2 \mathrm{LPH} \times 0.4 \mathrm{~m}$ is $82 \mathrm{~m}$, and the lateral head loss is $2 \mathrm{~m}$.

\section{Design of submains}

The flow rate of submain can be determined by using the total discharge and the required number of sections to be irrigated as given by Eq. 6. When the field is in trapezoidal, triangular and not rectangular in shape, the design can be made by adjusting the total discharge so the design chart made for rectangular fields can be used directly. Since the submain length is normally short, the submain size is designed for a single size and submain slope is assumed to be uniform and downslope [22].

$$
\begin{gathered}
\text { Flow rate of submain }=\frac{T_{d s}}{\text { Number of sections }} \\
=\frac{6745}{2}=3373 \mathrm{LPH} \\
=0.94 \mathrm{LPS}
\end{gathered}
$$

Referring to Table 3, with the discharge of 0.94 LPS (litres per second), the suitable size of sub-main is 40 $\mathrm{mm}, 6 \mathrm{Ksc}$. Total head loss in submain is $2 \mathrm{~m}$. The total length of submain required is $63.6 \mathrm{~m}$. Two (2) submains of $31.8 \mathrm{~m}$ each are placed at the centre of the field, and laterals are laid along both sides of the submain for 31.8 m length.

\section{Design of mainline}

For the design of the mainline, we refer to Table 4, the

\begin{tabular}{|c|c|c|c|c|c|c|c|c|}
\hline \multirow{3}{*}{$\begin{array}{l}\text { Dripper } \\
\text { spacing (m) } \\
\text { S }\end{array}$} & \multicolumn{4}{|c|}{$2 \mathrm{LPH}$} & \multicolumn{4}{|c|}{$4 \mathrm{LPH}$} \\
\hline & \multicolumn{2}{|c|}{$12 \mathrm{~mm}$} & \multicolumn{2}{|c|}{16 mm } & \multicolumn{2}{|c|}{$12 \mathrm{~mm}$} & \multicolumn{2}{|c|}{16 mm } \\
\hline & $L$ & $\mathrm{~N}$ & $L$ & $\mathrm{~N}$ & $\mathrm{~L}$ & $\mathrm{~N}$ & $L$ & $\mathrm{~N}$ \\
\hline 0.3 & 41 & 137 & 68 & 227 & 26 & 87 & 43 & 143 \\
\hline 0.4 & 49 & 123 & 82 & 205 & 31 & 78 & 52 & 130 \\
\hline 0.5 & 57 & 114 & 95 & 190 & 36 & 72 & 61 & 122 \\
\hline 0.6 & 64 & 107 & 107 & 178 & 41 & 68 & 68 & 113 \\
\hline 0.75 & 74 & 99 & 124 & 165 & 47 & 63 & 79 & 105 \\
\hline 0.9 & 83 & 92 & 140 & 156 & 53 & 59 & 89 & 99 \\
\hline 1 & 89 & 89 & 149 & 149 & 57 & 57 & 95 & 95 \\
\hline 1.25 & 103 & 82 & 173 & 138 & 66 & 53 & 110 & 88 \\
\hline 1.5 & 116 & 77 & 195 & 130 & 74 & 49 & 124 & 83 \\
\hline
\end{tabular}
PVC mainline data. Here, one submain will be operated

Table 2 Maximum in-line lateral running length in meters with a $7.5 \%$ discharge variation on flat ground (head loss $2 \mathrm{~m}$ ) [18]
Table 3 PVC submain flows

\begin{tabular}{lll}
\hline Size $\mathrm{mm} \mathrm{Ksc}$ & Max flow (LPS) & $\mathrm{HL}(\mathrm{m})$ \\
\hline 406 & Up to 1.8 & 2 \\
506 & 1.8 to 3 & 2 \\
634 & 3 to 5 & 2 \\
754 & 5 to 8 & 2 \\
\hline
\end{tabular}

at a time; therefore, discharge through the mainline is the same as the discharge through the submain, this is to say 0.94 LPS. Referring to Table 4, we see that 50 $\mathrm{mm} \times 6 \mathrm{Ksc}$ is suitable to carry the flow of $0.94 \mathrm{LPS}$.

From Table 4, it is observed that the head loss at maximum discharge, that is, at 1.8 LPS through a $50 \mathrm{~mm} \times 6$ Ksc PVC pipe is $30 \mathrm{~m}$, but a lesser discharge in this case (0.94 LPS). Therefore, for calculating actual head loss, reference is made to Table 5. It is found that for a 50$\mathrm{mm}$ pipe and for a 0.94-LPS flow, the head loss is $9.0 \mathrm{~m}$ for $1000 \mathrm{~m}$ length pipe, but the total length of main line is $100 \mathrm{~m}$. Hence, head loss through a $50-\mathrm{mm}$ pipe of $100 \mathrm{~m}$ length at $0.94 \mathrm{LPS}$ is

$$
=\frac{9.0 \times 100}{1000}=0.9 \mathrm{~m}
$$

The proposed model design layout for the 1-acre banana plantation field was designed as shown in Fig. 4. It consists of two rectangular sections of $31.8 \mathrm{~m}$ by $63.6 \mathrm{~m}$ each, mainline of $50 \mathrm{~mm}$ by $6 \mathrm{Ksc}$, submains of $40 \mathrm{~mm}$ by $6 \mathrm{Ksc}$, sand filter and a flush point valve.

\section{Design of pump/pump discharge}

The required pump discharge is 1.54 LPS. Assuming an operating pressure of $1 \mathrm{~kg} \mathrm{~cm}^{-2} \approx 10 \mathrm{~m}$ and lateral head loss of $2 \mathrm{~m}$ and in submains of $2 \mathrm{~m}$ as indicated in Table 6 and considering head loss from dripper to pump foot value, i.e. water source:

Table 4 PVC main line flows [18]

\begin{tabular}{lll}
\hline Size $(\mathrm{mm} \mathrm{Ksc})$ & Flow LPS & Head loss at max flow $(\mathrm{m} / \mathrm{m})$ \\
\hline $50 \times 6$ & 1 to 1.8 & $30 / 1000$ \\
$63 \times 4$ & 1.8 to 3.0 & $22 / 1000$ \\
$75 \times 4$ & 3.0 to 5.0 & $22.6 / 1000$ \\
$90 \times 4$ & 5.0 to 8.0 & $23 / 1000$ \\
$110 \times 4$ & 8.0 to 11.0 & $15 / 1000$ \\
$125 \times 4$ & 11.0 to 16.0 & $16 / 1000$ \\
$140 \times 4$ & 16.0 to 20.0 & $14 / 1000$ \\
$160 \times 4$ & 20.0 to 24.0 & $12.5 / 1000$ \\
$180 \times 4$ & 24.0 to 32.0 & $10.7 / 1000$ \\
$200 \times 4$ & 32.0 to 41.0 & $9.5 / 1000$ \\
\hline
\end{tabular}




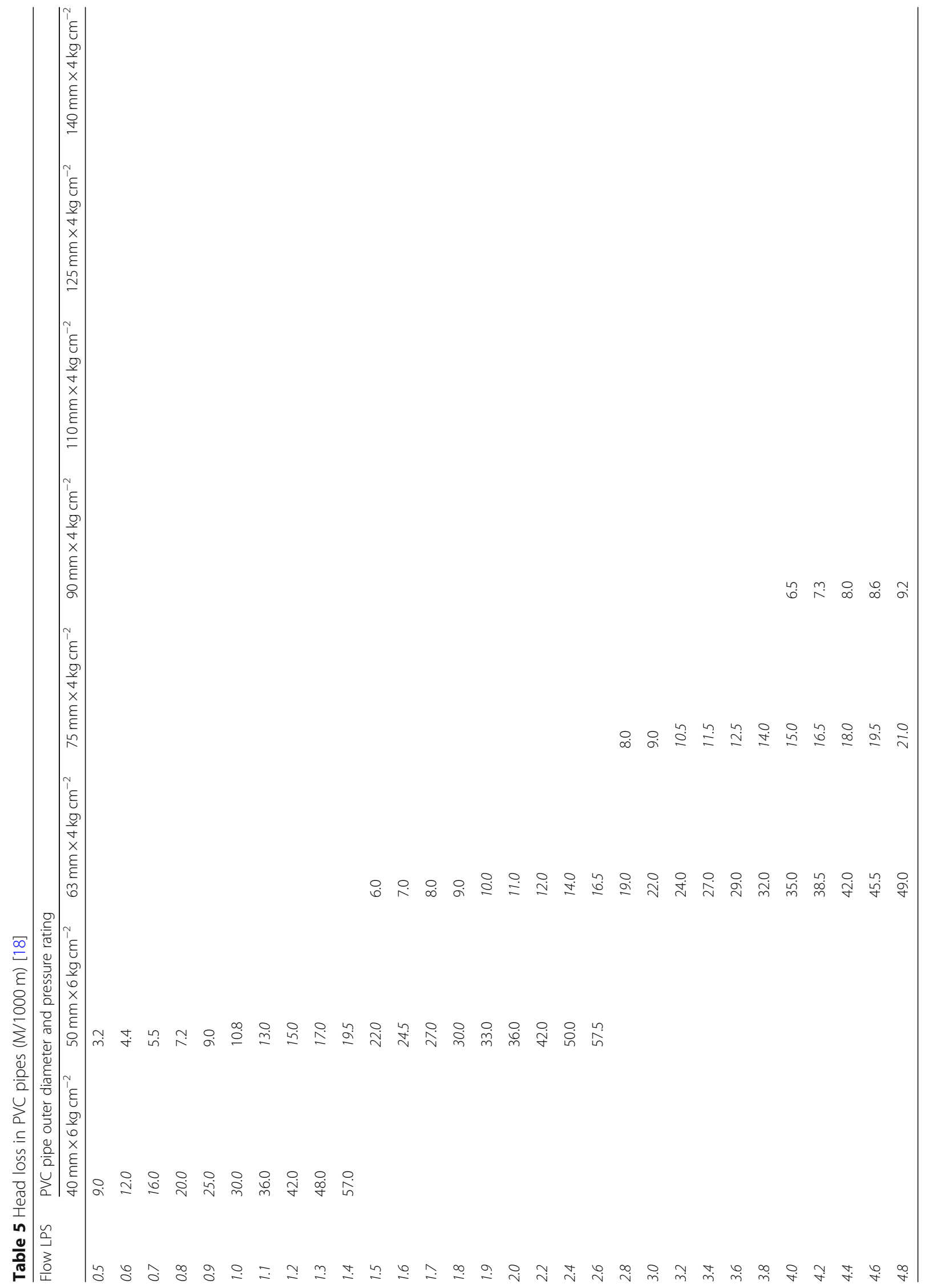




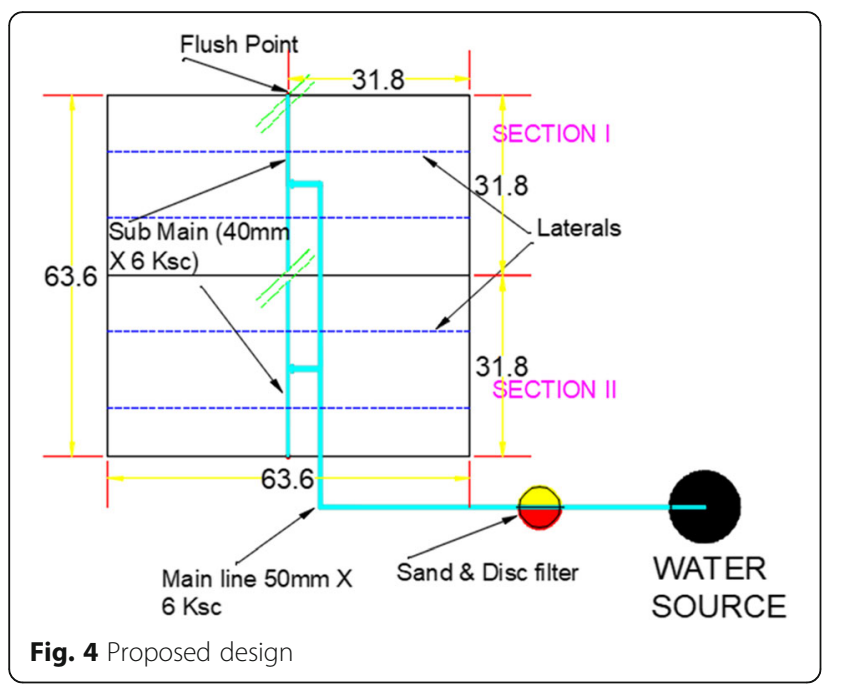

a. Operating pressure $=10 \mathrm{~m}$

b. Head loss in laterals $=2 \mathrm{~m}$

c. Head loss in submains $=2 \mathrm{~m}$

d. Head loss in mainline $=0.9 \mathrm{~m}$

e. Head loss in fittings (approx.) $=3 \mathrm{~m}$

f. Head loss in sand filter $=5 \mathrm{~m}$

g. Head loss in disc filter $=3 \mathrm{~m}$

h. Head loss in NRV (non-return valve) $=1 \mathrm{~m}$

i. Static suction and delivery $=8 \mathrm{~m}$

j. Static head of the field $=0 \mathrm{~m}$

k. Pump suction and delivery $=8 \mathrm{~m}$

Then, the total head will be equivalent to the sum of all heads listed above.

Total head $=(10+2+2+0.9+3+5+3+1+0+8) m$

Total head $=34.9 \mathrm{~m}$

Therefore, Eq. 7 was used to calculate the required pump horsepower $\left(P_{P}\right)$ with a discharge of 0.94 LPS at $34.9 \mathrm{~m}$ head.

Table 6 Head losses through different system components [18]

\begin{tabular}{ll}
\hline Item description & $\mathrm{m}$ \\
\hline Lateral & 2 \\
Submain & 2 \\
NRV & 1 \\
Hydrocyclone filter & 5 \\
Sand filter & 5 \\
Disc filter & 3 \\
Screen filter & 2 \\
Venturi/F.Tank & 5 \\
PVC fittings (approx.) & 3 \\
\hline
\end{tabular}

$$
\begin{gathered}
P_{P}=\frac{\text { Pump discharge }(Q) \text { in LPS } \times \text { total head }(m)}{45} \\
\mathrm{HP}=\frac{0.94 \times 34.9}{45} \\
=0.73 \text { hp water pump } \\
P_{P}=544 \mathrm{~W}
\end{gathered}
$$

\section{Operating schedule}

Since there are only two sections to be irrigated and using Eq. 6 pump discharge rate, Table 7 is the irrigation operating schedules for the proposed sections.

\section{Designing and sizing of the proposed solar-wind hybrid as per irrigation demand}

In this study, the major aim was to meet a daily irrigation pumping demand for the banana plantation. From Table 7, to irrigate the required two sections of banana plantation, 33,730 L of water will be required, where each section will be irrigated for $5 \mathrm{~h}$. Wind-solar electric energy generation by wind turbines and solar PV panels change between months depending on the available weather conditions that include solar irradiation, temperature, air density, wind speed, and air pressure. When the metrological data of Kalangala district (wind speed and solar periods) are put into consideration, it is assumed that more benefit will be gained from solar energy than from wind energy. There are more advantages in using hybrid wind and PV solar technologies as compared to using them separately [23]. Figure 5 is the proposed system connectivity with two inverters, battery, controller, solar panels, wind turbine and charger controller.

The following steps/procedures were adopted from [24] to design the proposed Kalangala irrigation solarwind hybrid system

a. Sizing and selection of solar panels

b. Sizing and selection of wind turbine

c. Sizing and selection of inverter power

d. Sizing and selection of charge controller

e. Sizing and selection of battery

\section{Sizing and selection of solar panel}

When the $544 \mathrm{~W}(0.73 \mathrm{hp})$ water pump runs for $10 \mathrm{~h} \mathrm{~d}^{-1}$ pumping water for irrigating bananas, the daily electric energy requirement to be met with solar panels is obtained from Eq. 8 which multiplies the power of the pump and the period of daily use. 
Table 7 Irrigation operating schedule for the banana plantation

\begin{tabular}{llllll}
\hline Sr. no & Section no. & Discharge L.P.H & Peak operation time $(\mathrm{h})$ & Area covered $(\mathrm{Ac})$ & Total volume of water required $(\mathrm{L})$ \\
\hline 1 & 1 & 3373 & 5 & 0.5 & 16,865 \\
2 & 2 & 3373 & 5 & 0.5 & 16,865 \\
Total & & 10 & 1.0 & 33,730 \\
\hline
\end{tabular}

Energy requirement $\left(P_{P V}\right)=N_{\text {pump }} \times$ operation time $(h)$ from Eq. 11, where $P_{\mathrm{AH}}$ is daily energy required (ampere $P_{P V}=544 \mathrm{~W} \times 10 \mathrm{~h}=5440 \mathrm{Wh} \mathrm{d}^{-1}$

By considering charge controller output at the wind turbine, and solar system as 95\% (AC-DC) and 90\% for (DC$\mathrm{AC}$ ) respectively, then the required power taking into account power efficiencies was calculated using Eq. 9 [23].

$$
\mathrm{PPC}=P_{P V} \div \eta \mathrm{CHARGE} \div \eta \mathrm{INV}=\frac{5440 \mathrm{Wh} / \mathrm{d}}{(0.95 \times 0.9)}=7442 \mathrm{Wh}^{-1}
$$

Oğuz [23] stated that if it is assumed that there might be general losses that might occur in the system considering the worst situations (cable losses, attachments, development current), then the total power needed per day can be obtained from Eq. 10 accounting for all lo8sses assumed to exist in the system.

$$
\begin{aligned}
(\text { Daily power need }) P_{\text {load }}=\mathrm{PPC} \times 1.1 & =7442 \mathrm{Wh} \mathrm{d}^{-1} \\
& \times 1.1=8186.2 \mathrm{Wh} \mathrm{d}^{-1}
\end{aligned}
$$
$\mathrm{h}^{-1}$ ) and $V_{\text {system }}$ is the battery voltage

$$
P_{\text {Ah }}=\frac{P_{\text {load }}}{V_{\text {system }}}=\frac{8186.2 \mathrm{Wh} \mathrm{d}^{-1}}{12 v}=682.2 \mathrm{Ahd}^{-1}
$$

From the research conducted by Okou [11], Kalangala's average wind speed was $5.88 \mathrm{~m} \mathrm{~s}^{-1}$ and the average monthly horizontal was $146.67 \mathrm{kWh} \mathrm{m}^{-2}$, and the average solar irradiance of $4.89 \mathrm{kWh} \mathrm{m}^{-2} \mathrm{~d}^{-1}$ was recorded. The island receives an average of 11 sunshine $\mathrm{h} \mathrm{d}^{-1}$ [11]. Therefore, Eq. 12 was then used to obtain the necessary PV panel current value, where $I_{\mathrm{pv}}$ is the required panel current.

$$
\begin{aligned}
I_{\mathrm{pv}} & =\frac{P_{\mathrm{Ah}}}{\text { Average sunshine }(h)}=\frac{682.2 \mathrm{Ah} \mathrm{d}^{-1}}{11 \mathrm{~h}} \\
& =62 \mathrm{~A}(\text { as required current to be generated per day })
\end{aligned}
$$

The daily energy requirement (ampere $\mathrm{h}^{-1}$ ) for pumping irrigation water to the field was then determined

From the calculations above, the selected suitable panel make for the study was Zedfabric ${ }^{\mathrm{Tm}}$, and the technical specifications for the selected panels is given in Table 8.

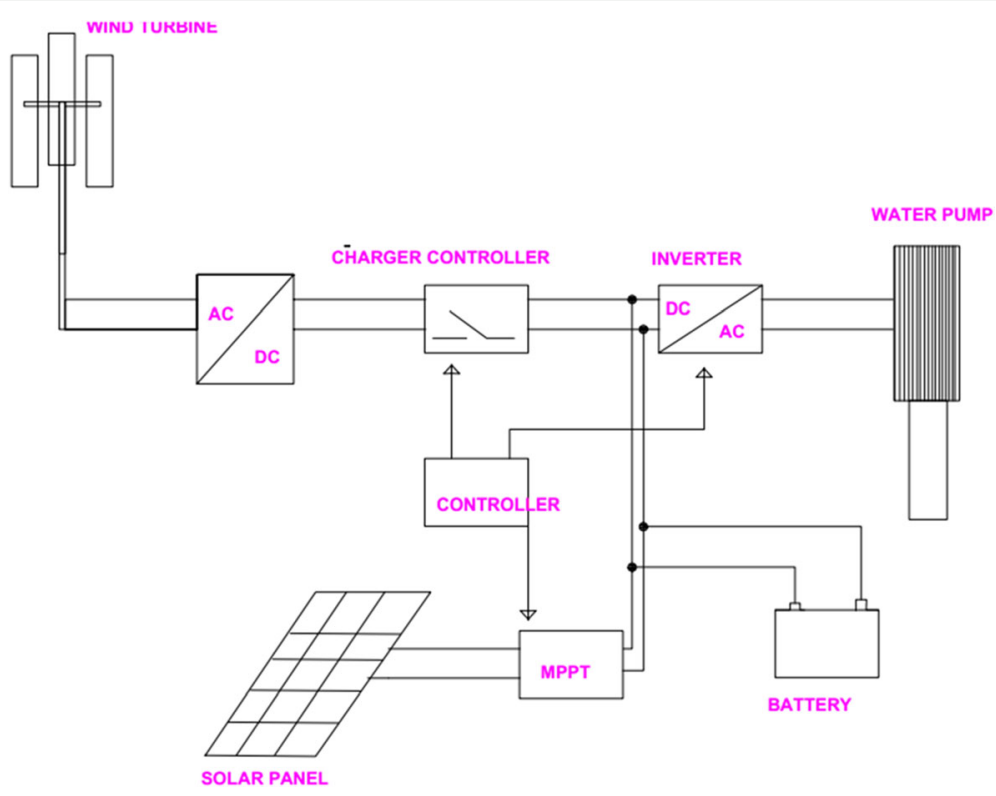

Fig. 5 System connection schema 


\section{Determining the solar panels required for the hybrid}

The solar panels required for the hybrid system was obtained from Eq. 13 [23].

$$
\begin{aligned}
\text { No.of panels } & =\frac{I_{\mathrm{pv}}}{\text { Selected panel short circuit current }} \\
& =\frac{62 \mathrm{~A}}{5.23 \mathrm{~A}}=11.85 \approx 12 \text { panels }
\end{aligned}
$$

\section{Sizing and selection of wind turbine}

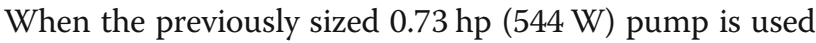
to pump water for $10 \mathrm{~h} \mathrm{~d}^{-1}$, the electric energy requirement to be met with the energy from the wind was calculated from Eq. 14.

$$
P_{\mathrm{wt}}=P_{\text {pump }} \times t
$$

where $P_{w t}$ is the energy required in the wind and $P_{\text {pump }}$ is the power of the pump (watts)

$$
P_{\mathrm{wt}}=544 \mathrm{~W} \times 10 \mathrm{~h}=5440 \mathrm{Whd}^{-1}
$$

\section{Average energy requirement $\left(P_{\text {load }}\right)$}

The average energy requirement for the wind turbine was given by Eq. 15

$$
\begin{aligned}
\left(P_{\text {load }}\right)=\frac{P_{\mathrm{wt}}}{\eta \text { Charge } \times \eta I N V} & \times 1.1\left(P_{\text {load }}\right)=\frac{5440 \mathrm{Wh} \mathrm{d}^{-1}}{(0.9 \times 0.95)} \\
& \times 1.1=6999 \mathrm{Whd}^{-1}
\end{aligned}
$$

\section{Wind turbine design}

\section{Daily energy requirement}

According to Oğuz [23], the daily energy required of a wind turbine in amperes per hour can be obtained using Eq. 16.

Table 8 Proposed solar panel specification

\begin{tabular}{lll}
\hline S. no & Item description & Value \\
\hline 1 & Maximum power & $180 \mathrm{~W}_{p}$ \\
2 & $180 \mathrm{~W}_{p}$ dimensions & $1581 \times 809 \times 50 \mathrm{~mm}$ \\
3 & Number of cells & 72 \\
4 & Voltage at $P_{\max }$ & 36.31 \\
5 & Current at $P_{\max }$ & 4.98 \\
6 & Open circuit voltage $(\mathrm{V})$ & 44.97 \\
7 & Short circuit current $(\mathrm{A})$ & 5.23 \\
8 & Maximum system voltage $(\mathrm{V})$ & 1000 \\
9 & Temperature range & -40 to $80^{\circ} \mathrm{C}$ \\
10 & Module efficiency & $>15.2 \%$ \\
\hline
\end{tabular}

$$
P_{\text {Ah }}=\frac{P_{\text {load }}}{V_{\text {system }}}=\frac{6999}{12}=583.3 \mathrm{Ah} \mathrm{d}^{-1}
$$

\section{Determining wind turbine blade radius}

From Eq. 17, the blade radius of the turbine capable of generating the desired power was calculated [23].

$$
R=\sqrt{\frac{P}{\rho V_{0}^{3} \mathrm{ARC}_{p}}}
$$

where $(A R)=h / R$ is the turbine's aspect ratio which is the ratio between blade height and rotor radius. For this study, a Darrieus VAWT was selected with an aspect ratio of 2 (Fig. 6) since its rotor can take wind from any direction and needs low wind speeds to start [25].

Output coefficient $\left(C_{\mathrm{P}}\right)$ of a two-blade high-speed turbine varies between 0.4 and 0.5 , and the $C_{\mathrm{P}}$ for a lowspeed wind turbine with more than 2 blades ranges from 0.2 to 0.45 [23].

\section{Calculating design parameters for the wind turbine}

The annual average Kalangala district wind speed for 8 years at $10 \mathrm{~m}$ is $5.27 \mathrm{~m} \mathrm{~s}^{-1}$, and transferring this value from $10 \mathrm{~m}$ height to $30 \mathrm{~m}$ is given by Hellman equation (18) [26].

$$
V=V_{o}\left(\frac{h}{h_{0}}\right)^{\alpha}
$$

where $V=$ speed to the height $h, V_{o}$ is speed to the height $h_{\mathrm{o}}$ (frequently referred to as $10 \mathrm{~m}$ height) and $\propto$ is the friction coefficient or Hellman exponent. "This coefficient is frequently assumed as a value of $1 / 7$ for open land and is a function of the topography at a specific site," [27]. Table 9 is the friction coefficient of various landscapes.

$$
V=5.27\left(\frac{30}{10}\right)^{0.10}=6 \mathrm{~m} \cdot \mathrm{s}^{-1}
$$

The calculated energy requirement $\left(P_{\text {Load }}\right)$ for irrigating the banana plantation is $6999 \mathrm{Wh} \mathrm{d}^{-1}$, the annual energy requirement was then obtained;

$$
=\left(\frac{6999 \mathrm{Wh} \mathrm{d}^{-1}}{1000} \times 365 \text { days }\right)=2555 \mathrm{kWh}
$$

The size of the wind turbine that is required to be installed to meet the energy demand or requirement was determined based on the following assumptions.

1. Coefficient of performance $=0.4$

2. Density of air $=1.225 \mathrm{~kg} \mathrm{~m}^{-3}$ 


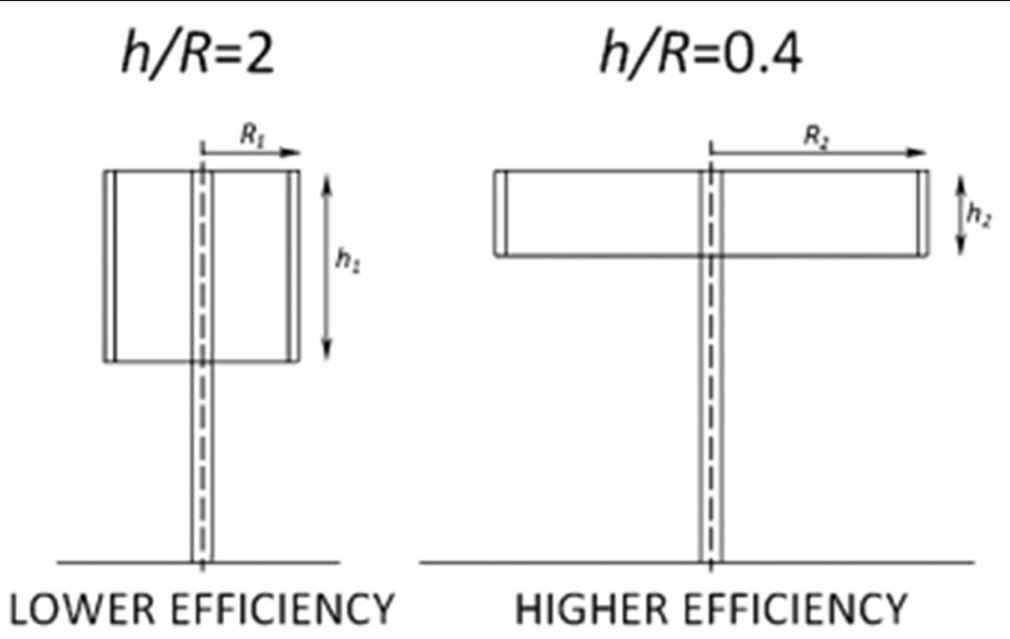

Fig. 6 Efficiencies of different aspect ration

3. Capacity factor $\left(C_{p}\right)$ of 0.30 (that is to say $30 \%$ of the time wind machine is producing energy at rated power)

4. The transmission losses of rotor to generator $=0.9$

5. Generator losses of 0.9

6. Number of operational hours per year $8760 \mathrm{~h}$

\section{Power density of the wind (power/unit area)}

The power density (PD) of moving air is given by Eq. 19 [28].

$$
\mathrm{WPD}=\frac{1}{2} \rho V^{3}
$$

where WPD is the wind power density, $\rho$ is the air density and $\mathrm{V}$ is the wind speed. Air density is determined according to varying sea level degrees of accuracy.

$$
\begin{aligned}
& \text { WPD }=\frac{1}{2} \times \text { air density } \times(\text { velocity })^{3} \\
& =0.5 \times 1.225 \times(6.0)^{3}=132.3 \mathrm{~W} \mathrm{~m}^{-1}
\end{aligned}
$$

Table 9 Friction coefficient $\propto$ for a variety of landscapes

\begin{tabular}{ll}
\hline Landscape type & Friction coefficient $\propto$ \\
\hline Lakes, ocean and smooth hard ground & 0.10 \\
Grasslands (ground level) & 0.15 \\
Tall crops, hedges and shrubs & 0.20 \\
Heavily forested land & 0.25 \\
Small town with some trees and shrubs & 0.30 \\
City area with high rise buildings & 0.4 \\
\hline
\end{tabular}

Actual wind power density to be converted to useful energy

According to [23], the actual power density as shown in Eq. 20 is a product of wind power density, capacity factor, transmission and generator losses.

$=\mathrm{WPD} \times C_{p} \times$ Transmission loss $\times$ generator loss Actual power density $=132 \times 0.4 \times 0.9 \times 0.9$

$$
=43 \mathrm{~W} \mathrm{~m}^{-2}
$$

\section{Annual useful energy density}

The annual useful wind energy density was obtained as a product of wind power density and total operational hours per year as shown in Eq. 21.

$$
\begin{gathered}
=\mathrm{PD} \times \text { number of hours per year } \\
=43 \times 8760=377 \mathrm{kWh} \mathrm{m}^{-2}
\end{gathered}
$$

The rotor size and turbine rating estimation

A wind turbine rotor is the organ that transforms the kinetic energy of wind to mechanical energy. For this reason, it is very important for wind turbines. As shown in Eq.. 22, the rotor size was determined from the swept area of the turbine.

$$
\begin{aligned}
\text { Swept } a \text { rea }= & \frac{\text { Total annual energy required }}{\text { Useful energy density }} \\
& \begin{array}{c}
2555 \mathrm{kWh} \\
\begin{array}{c}
377 \mathrm{kWh} \mathrm{m}^{-2} \\
=6.8 \mathrm{~m}^{2}
\end{array}
\end{array}
\end{aligned}
$$

But the swept area for the Darrieus or Savonious wind turbine can also be obtained from Eq. 23 
Swept area $\left(\mathrm{m}^{2}\right)=\mathrm{D} * \mathrm{~h}$

where $h$ is the height, $D$ is diameter of rotor and $D$ $=2 \mathrm{R}$

Using an aspect ratio of 2 (for turbines with more than two blades), that is, $(A R)=\frac{h}{R}$ therefore, $\frac{h}{R}=2$, then $h=$ $2 R$.

From Eq. 23, we obtained the swept area.

$$
\begin{aligned}
& 6.8 \mathrm{~m}^{2}=D * h=D * 2 R=2 R * 2 R=4 R^{2} \\
& R=1.3 \mathrm{~m}
\end{aligned}
$$

The height of the blades was then obtained from the aspect ratio as given in Eq. 24.

$$
\begin{gathered}
\text { Aspect ratio }(A R)=\frac{h}{R} \\
2=\frac{h}{R}=\frac{h}{1.3} \\
h=2.6 \mathrm{~m}
\end{gathered}
$$

\section{Power rating of the turbine}

The output of a wind turbine depends on the turbine's size and the wind's speed through the rotor [29]. The turbine rated power as shown in Eq. 25 was obtained

$$
\begin{gathered}
=\text { Actual PD } \times \text { area of the rotor } \\
=(43 \times 6.8) \mathrm{W} \\
=0.292 \mathrm{~kW}
\end{gathered}
$$

\section{Actual rated power of the turbine rating}

"The capacity factor is defined as the actual power output over a certain period of time as a proportion of a wind turbine/facility's maximum capacity" [30]. Equation 26 was then used to estimate the actual rated power and a capacity factor $C_{\mathrm{P}}$ of 0.30 was selected for the study (that is to say, $30 \%$ of time wind machine produces energy at the rated power).

$$
\begin{gathered}
\frac{\text { Power rating }}{\text { Capacity factor }} \\
=\frac{0.292}{0.30}=0.97 \mathrm{~kW} \approx 1 \mathrm{~kW}
\end{gathered}
$$

Thus, a 1-kW rated power wind turbine would provide desired annual energy under the given situation

\section{Speed of the turbine}

According to Ragheb [31], for grid-connected wind turbines with three rotor blades, optimal wind tip speed ratio has to be reported as 7 , with values over the range 6-8. Therefore, Eq. 27 was then used to determine the required speed of the turbine.

$$
\begin{aligned}
& \text { Speed of Turbine }(\mathrm{rpm}) \\
& =\frac{\text { Wind speed } \times 60 \times \mathrm{TSR}}{\text { Circumference }}
\end{aligned}
$$

where TSR is the tip speed ratio (7)

$$
\text { Speed of turbine }(\mathrm{rpm})=\frac{6.0 \times 60 \times 7}{4 \pi}=200.5 \mathrm{rpm}
$$

\section{Assumptions made}

The above power rating is based on the assumption that the average Kalangala district wind speed of $6.0 \mathrm{~m} \mathrm{~s}^{-1}$ at $30 \mathrm{~m}$ height will be available through the year, $8760 \mathrm{~h}$, which is not the case, and that is why we have taken the capacity factor into account.

\section{Technical specification of the required wind turbine (1 kW)}

As per the calculations above, a wind turbine was selected with similar specifications and Table 10 is the specifications for the proposed turbine.

\section{Hybrid solar-wind system operational experimental description}

This hybrid solar-wind system considered as a case study is a combination of wind and photovoltaic subsystems as shown in Fig. 5 above. Basing on the design calculations, a $1-\mathrm{kW}$ wind subsystem was selected for this system, and its generator was equipped with a direct driven permanent-magnet synchronous generator, diode rectifier and (DC/DC) converter for the tracking of maximum power point $[19,20]$. There are 12 photovoltaic panels of $5.23 \mathrm{~A}$. The variable $\mathrm{DC}$ output voltage from the panels is controlled by another (DC/DC) buck used for the MPPT through regulating the output current IPV. The common DC bus collects the total energy from the photovoltaic subsystems and wind and uses it partly to charge the battery bank and partly to supply the weak grid to the water pump (AC load) via a single-phase

Table 10 Proposed wind turbine parameters

\begin{tabular}{lll}
\hline S. no. & Item description & Value \\
\hline 1 & Start-up wind speed & $2 \mathrm{~m} \mathrm{~s}^{-1}$ \\
2 & Rated wind speed & $9 \mathrm{~m} \mathrm{~s}^{-1}$ \\
3 & Blades diameter (m) & $2.7 \mathrm{~m}$ \\
4 & Rated speed & $400 \mathrm{RPM}$ \\
5 & Pipe size & $4.5^{\prime \prime}$ \\
6 & Blades quantity & $3 \mathrm{pcs}$ \\
7 & Blade material & Reinforced fibre glass \\
8 & Rated output power & $1 \mathrm{~kW}$ \\
9 & Stop method & Electromagnetic brakes \\
10 & Voltage & $48 \mathrm{~V}$ \\
11 & Maximum power output & $1500 \mathrm{~W}$ \\
\hline
\end{tabular}


inverter. Figures 7 and 8 show respectively the block diagrams of proposed maximum power point tracking control for PV subsystems and the wind [32].

\section{Sizing and selection of inverter for the proposed hybrid}

For this study, one inverter was proposed to be used for both wind turbine and solar panels, making the system more convenient and on reducing the complexity of the system. Considering inverter output of $90 \%$, the required inverter value was given by Eq. 28 .

$$
P_{\text {inverter }}=\frac{P_{P}(\mathrm{~W})}{\eta_{\mathrm{INV}}}
$$

where $P_{\text {inverter }}$ is the inverter power in watts

$$
=\frac{544 \mathrm{~W}}{0.9}=604.4 \mathrm{~W}
$$

It was assumed that the irrigation pump would draw excess current for a short time and that $700 \mathrm{~W}$ full sine inverter should be selected of which is not far from the calculated value of $604.4 \mathrm{~W}$. The technical specifications for the proposed inverter are given in Table 11 .

\section{Sizing and selecting the system battery}

Accumulators are assumed to be used in the system to store DC voltage from solar panels and wind turbine. The objective is to store surplus electric energy generated from the panels and turbine into accumulators.

$$
\text { Required accumulator value for the system }\left(P_{\mathrm{Ah}}\right)
$$$$
=\frac{P_{\text {load }}(\text { solar })+P_{\text {load }}(\text { wind })}{V_{\text {battery }}}
$$

where $P_{\text {load }}$ in this case is power loads from Eq. 10 and Eq. 15 respectively and $V_{\text {Battery }}$ the battery voltage

$$
=\frac{(8186.2) \mathrm{Wh}+(6999) \mathrm{Wh}}{12 \mathrm{~V}}=1265.4 \mathrm{Ah}
$$

For this study, a 200-Ah battery was selected to be used for the system, and the number of batteries required was obtained from Eq. 30.

$$
\begin{aligned}
\text { Number of batteries required }= & \frac{\text { System's required accumulator value }}{\text { Selected battery size }(\mathrm{Ah})} \\
& =\frac{1265.4 \mathrm{Ah}}{200 \mathrm{Ah}}=6.33 \approx 7 \text { batteries }
\end{aligned}
$$

\section{Finite element analysis of the turbine}

The wind turbine was designed using SolidWorks 2019 software as shown in Fig. 9, with a blade height of 2.82 $\mathrm{m}$ and a radius of $1.41 \mathrm{~m}$. The model was then simulated in SolidWorks 2019 flow simulation environment, and therefore, the turbine flow behaviour, static pressure, turbulence intensity and stress distribution was analysed at three times the peak wind speed of Kalangala district at an elevation of $30 \mathrm{~m}$ (that is to say at $20 \mathrm{~m} \mathrm{~s}^{-1}$ ), and the results are shown in Figs. 10 and 11.

\section{Cost analysis}

Since the wind-solar hybrid system is a long-term efficient alternative in pumping water for irrigation in comparison to other types of energy, it is important that the cost remains as low as possible. Table 12 shows the total investment of the Kalangala proposed solar-wind hybrid irrigation system.

\section{Investment}

The design lifetime of a typical wind turbine (VAWT/ HAWT) is 20 years, with low turbulence of lake offshore wind conditions causing very low vibrations and fatigue stresses [33].

Total project cost $=73,812,000 \mathrm{UGX}$

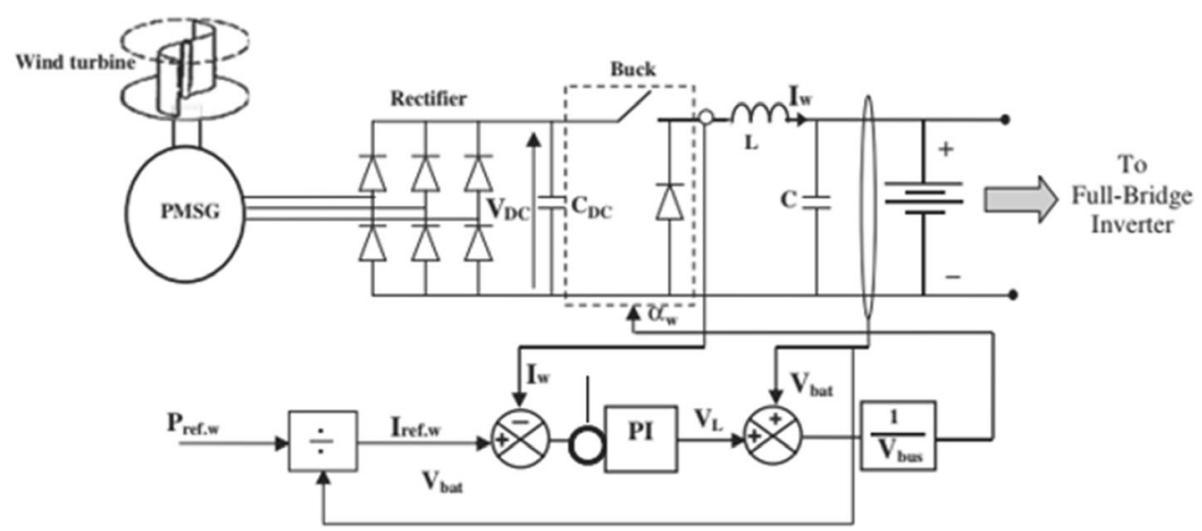

Fig. 7 Current control of wind-side (DC/DC) chopper 


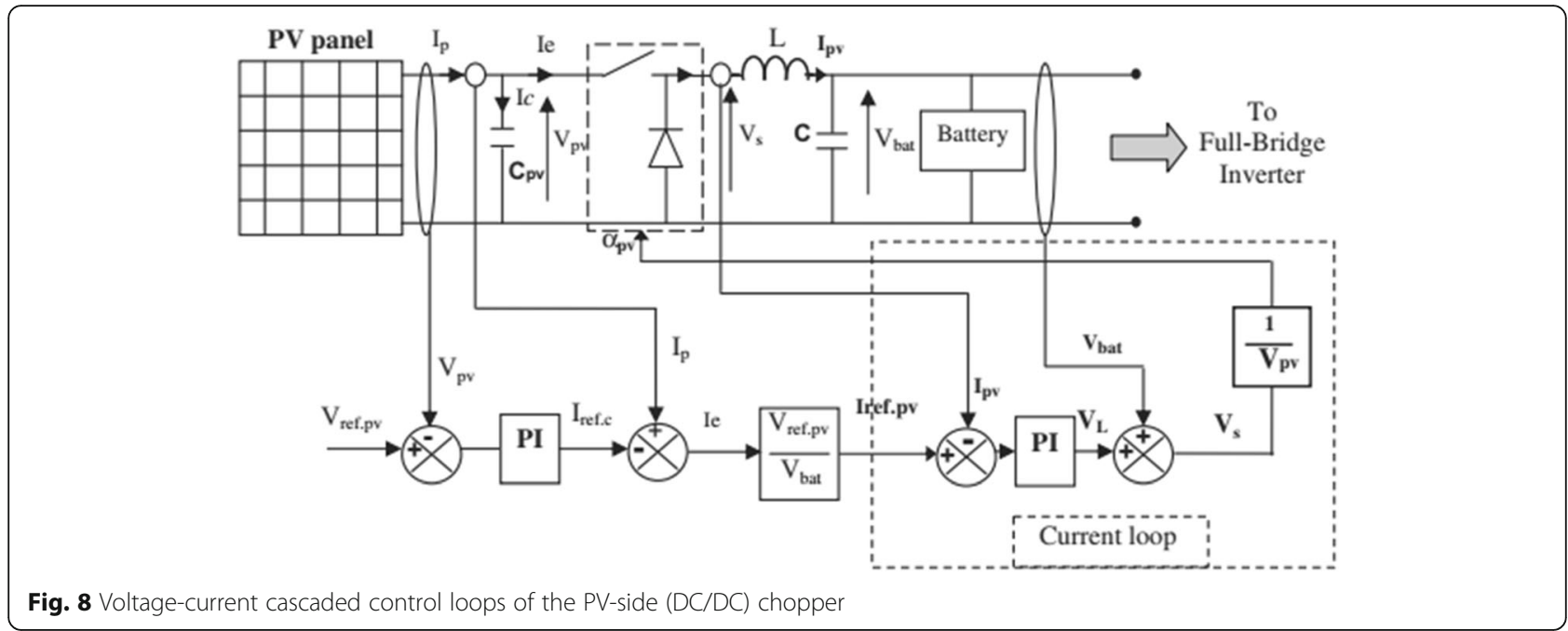

\section{Payments}

The payments, including the initial payments/cash flows, were used to calculate the net present value and the real rate of return over a 5-year project time since this is the main economic aspect of the analysis. For simplicity, tax payments, credits and depreciation credits were not considered [33].

Assuming that the capital cost for the project is obtained as a loan, then the interest payment on the loan was put into consideration.

\section{Operation and maintenance}

According to Blanco [33], the maintenance and operational cost of a wind turbine is $15 \%$ of the total project cost without the labour cost

\section{Maintenance/operation cost $=1.5 \%$ of (total project cost-labour cost)}

Table 11 Specification for the proposed inverter

\begin{tabular}{ll}
\hline Description & Value \\
\hline Model no & SK700-212 \\
Rated power & $700 \mathrm{~W}$ \\
Surge power & $1400 \mathrm{~W}$ \\
AC. voltage & $230 / 240 \mathrm{~V}$ \\
Frequency & $50 / 60 \mathrm{HZ}$ \\
No-load current draw & $1.20 \mathrm{~A}$ \\
DC voltage & $12 \mathrm{VDC}$ \\
Over voltage & $15.3 \mathrm{VDC}$ \\
Voltage range & $10.5-15.0 \mathrm{VDC}$ \\
Standby current draw & $0.25 \mathrm{~A}$ \\
Efficiency & $91 \%$ \\
Output waveform & True sine wave
\end{tabular}

$$
\begin{aligned}
= & 0.015 \times(73,812,000-3,000,000) \\
& =1,062,180 \mathrm{UGX} / \text { per year }
\end{aligned}
$$

\section{Total expenditure}

$=$ Total project cost + operation \& maintenance cost over expected lifetime

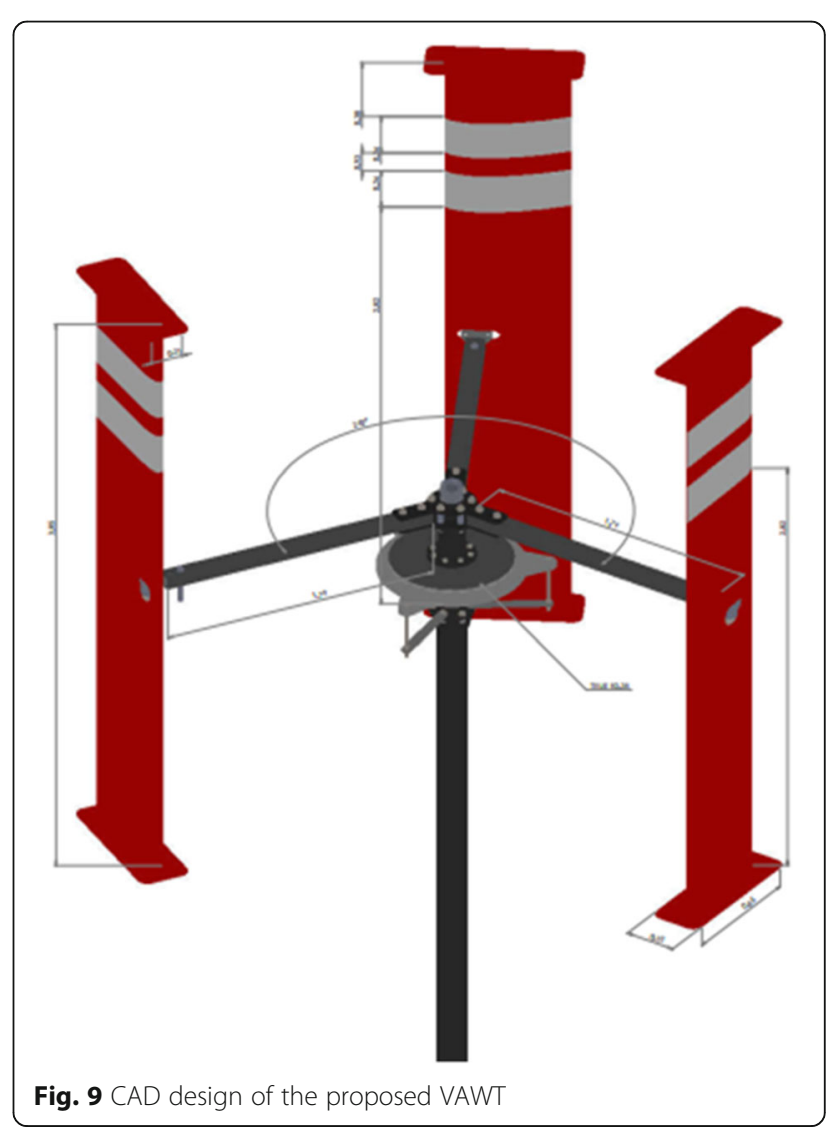




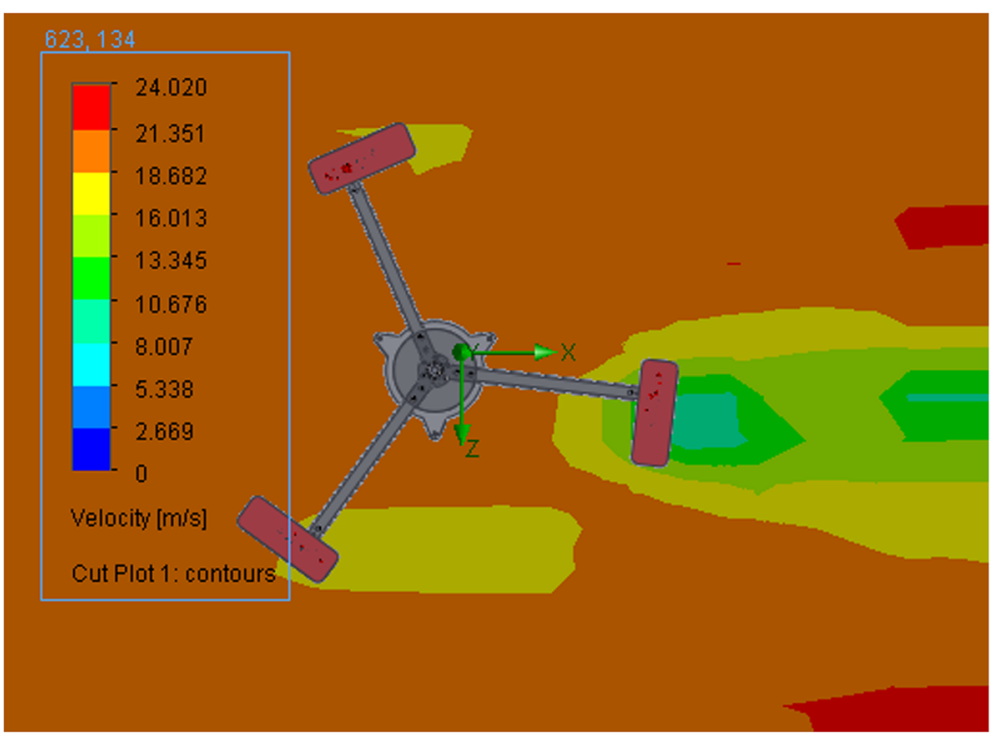

Fig. 10 Top view of proposed wind turbine cut plot

$$
\begin{aligned}
& =\left(73,812,000+\left(\frac{1,062,180}{\text { one year }}\right) \times 5 \text { year }\right) \\
& =79,122,900 \text { UGX }
\end{aligned}
$$

\section{Current income and expenditures per year}

The proposed area for banana plantation is 1 acre $\left(4046.86 \mathrm{~m}^{2}\right)$, and the proposed banana variety is
Nakytengu with a spacing is $10 \mathrm{ft} . \times 10 \mathrm{ft} .\left(9 \mathrm{~m}^{2}\right)$. Therefore, the number of banana plants to be planted is 450 .

\section{Assumption}

Price of a mature banana bunch is 9000 UGX.

Banana plant is a perennial crop which takes 9 months on average to grow and produce a bunch of bananas [34].

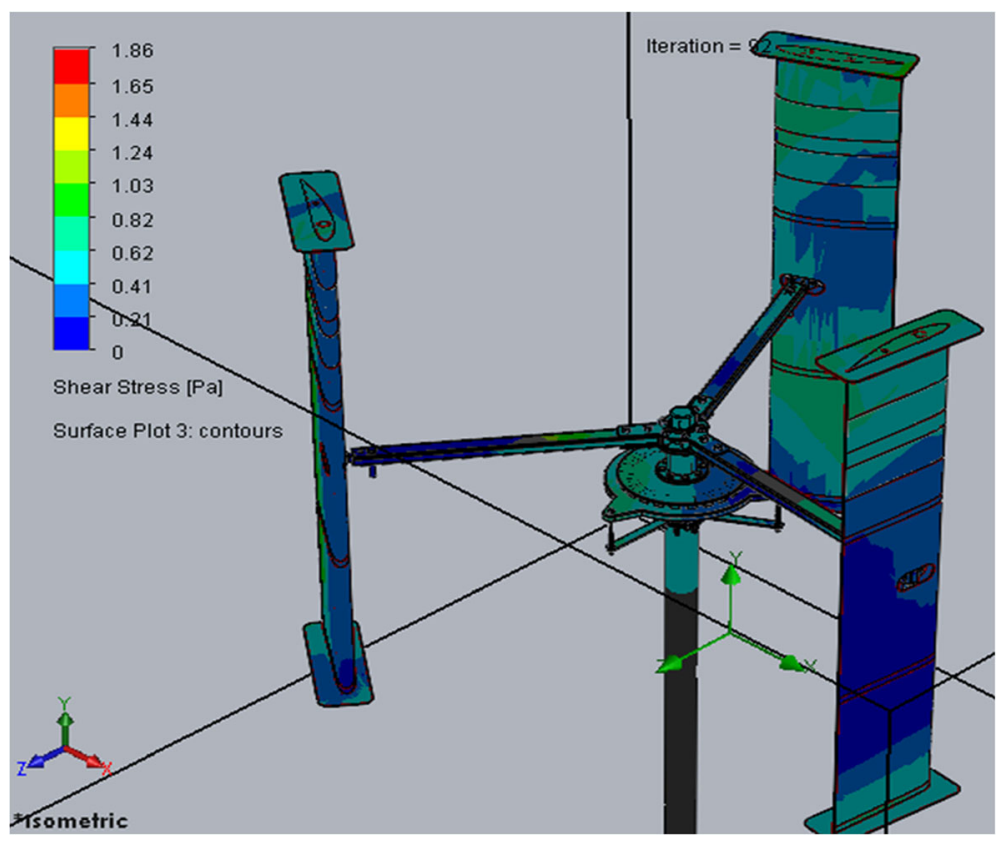

Fig. 11 Shear stress surface plot of the proposed design 
Table 12 Cost of proposed system components (UGX)

\begin{tabular}{llll}
\hline Item & Price & Qty & Cost \\
\hline Submersible borehole pump & $9,418,000$ & 1 & $9,418,000$ \\
700 W sine wave inverter & 300,000 & 1 & 300,000 \\
Sealed solar battery 200 Ah 12V & $1,530,000$ & 7 & $10,710,000$ \\
PVC borehole pipes size 1.5" & 68,000 & 85 & $5,780,000$ \\
Concrete tank (100m ${ }^{3}$ ) & $18,700,000$ & 1 & $18,700,000$ \\
Wind turbine c/w controller & $4,216,000$ & 1 & $4,216,000$ \\
Multicrystalline solar modules & $1,224,000$ & 12 & $14,688,000$ \\
Labour/installation & $3,000,000$ & 1 & $3,000,000$ \\
1 kW Darrieus wind turbine & $7,000,000$ & 1 & $7,000,000$ \\
Total cost & & & $73,812,000$ \\
\hline
\end{tabular}

\section{Gross yearly income}

Gross yearly income from sell of banana bunches assuming all plants have put on fruits is:

$$
\begin{aligned}
& =(15,000 \mathrm{UGX} \times 450) \\
& =4,050,000 \mathrm{UGX} / \text { year }
\end{aligned}
$$

\section{Net income stream per year}

$$
\begin{aligned}
& =(\text { gross yearly income }- \text { operation\&maintenance cost }) \\
& =(4,050,000-1,062,180) \mathrm{UGX} \\
& =2,987,820 \mathrm{UGX}
\end{aligned}
$$

Table 13 was then constructed over the 5 years for the solar-wind hybrid for banana field irrigation.

Net present value of income stream at $r=5 \%$ per year real rate of interest is $12,935,468$ UGX.
Yearly net real rate of return (after 5 years)

$$
\begin{aligned}
= & \frac{\text { Net present value of income stream }}{\text { Total project cost }} \\
& \times \frac{1}{5 \text { years }}
\end{aligned}
$$

$$
\frac{12,935,468 \mathrm{UGX}}{73,812,000} \times \frac{1}{5}=0.0351=3.5 \% \text { per year }
$$

\section{Results and discussions Proposed hybrid system}

Water required for irrigating 450 banana plants per day is $34 \mathrm{~m}^{3} \mathrm{~d}^{-1}$. The required irrigation time is $5 \mathrm{~h} \mathrm{~d}^{-1}$. Maximum field sections required for irrigation 1 acre are two sections, the required pump horsepower is 544 $\mathrm{W}$, and the number of solar panels at rating of $5.23 \mathrm{~A}$ required are 12 pieces. The design turbine speed is 201 r.p.m., and the rating of the wind turbine required for the system is $1 \mathrm{~kW}$. The inverter size is $700 \mathrm{~W}$, and the number of batteries required by the system is seven pieces at rating of $200 \mathrm{Ah}$. From optimization results, the total project cost is $73.8 \mathrm{~m} \mathrm{UGX}$ and the net income stream of $2.99 \mathrm{~m}$ UGX per year with yearly net real rate of return of $3.5 \%$ per year. The major demerits of independent renewable energy sources are unavailability at all times when needed and high capital cost and energy unavailability of rated wind speed requirement. Thus, a hybrid energy system (solar-wind) helps in overcoming the drawbacks of renewable energy sources and thus provides a continuous supply of electricity.

\section{Conclusion}

Solar-wind hybrid energy system is the most feasible economic solutions in lowering electricity bills; it also avoids the high costs encountered during extending grid power lines to remote areas and provides a clean renewable non-polluting source of electricity. In this paper, the water requirement for irrigating one acre of Nakytengu banana plantation in Kalanga district was

Table 13 Benchmark present value calculation for a the proposed solar-wind hybrid banana field irrigation system

\begin{tabular}{llllll}
\hline Year $n$ & $\begin{array}{l}\text { Expenditures } \\
\text { UGX }\end{array}$ & $\begin{array}{l}\text { Gross income } \\
\text { stream UGX }\end{array}$ & $\begin{array}{l}\text { Net income } \\
\text { stream UGX }\end{array}$ & $\begin{array}{l}\text { Present value f } \\
\text { actor } 1 /(1+r)^{n} \\
r=0.05\end{array}$ & $\begin{array}{l}\text { Net present value of } \\
\text { income stream UGX }\end{array}$ \\
\hline 0 & $-79,122,900$ & - & - & - & - \\
1 & $-1,062,180$ & $4,050,000$ & $2,987,820$ & 0.9524 & $2,845,600$ \\
2 & $-1,062,180$ & $4,050,000$ & $2,987,820$ & 0.9070 & $2,709,953$ \\
3 & $-1,062,180$ & $4,050,000$ & $2,987,820$ & 0.8638 & $2,580,879$ \\
4 & $-1,062,180$ & $4,050,000$ & $2,987,820$ & 0.8227 & $2,458,080$ \\
5 & $-1,062,180$ & $4,050,000$ & $2,987,820$ & 0.7835 & $2,340,957$ \\
Total & $-84,433,800$ & $20,250,000$ & $14,939,100$ & 4.3294 & $12,935,468$ \\
\hline
\end{tabular}


determined, pipeline for the irrigation system and design layout made, power to meet the irrigation demand determined and a solar-wind hybrid system sized for supplying the required electric power for irrigation. The system was simulated for flow behaviour, static pressure, turbulence intensity and stress at a speed, three times the average wind speed of Kalangala district elevated at $30 \mathrm{~m}$ above sea level, and the results showed that the system could still work properly without undergoing through deformation. Project cost analysis was made, and the results showed the project's yearly net real rate of return of $3.5 \%$ per year, indicating that the project is feasible. Thus, the analysis performed in this paper will set guidelines for energy consultants or engineers and for those who want to set up a solar-wind irrigation system for drip irrigation.

\section{Abbreviations}

AC: Alternating current; AR: Aspect ratio; DC: Direct current; HAWT: Horizontal axis wind turbine; L.P.H: Litres per hour; LPS: Litres per second; MPPT: Maximum power point tracking; NACRRI: National Crops Resources Research Institute; NPHC: National Population and Housing Census; NRV: Non-return valve; PD: Power density; PV: Photovoltaic; PVC: Polyvinyl chloride; UBOS: Uganda Bureau of Statistics; VAWT: Vertical axis wind turbine; WPD: Wind power density

\section{Acknowledgements}

Not applicable

\section{Authors' contributions}

SS devised the main conceptual ideas; collected, processed, and analysed the data; and wrote major parts of the paper. NK contributed to the methodological design, supervised and critiqued data collection and analysis, revised the manuscript, and made the suggestions for improvements. NB contributed to the case study description, revised the manuscript, and made the suggestions for improvement. All authors read and approved the final manuscript.

\section{Funding}

The fund for data collection was obtained from the Makerere University Department of Agricultural and Bio-engineering

\section{Availability of data and materials}

Not applicable

\section{Ethics approval and consent to participate}

Not applicable

\section{Consent for publication}

All the authors agreed to publish the article.

\section{Competing interests}

The authors declare that they have no competing interests.

Received: 4 March 2019 Accepted: 9 January 2020

Published online: 28 January 2020

\section{References}

1. UBOS, "Uganda Bureau of Statistics 2017 Statistical Abstract." [Online]. Available: https://www.ubos.org/wp-content/uploads/publications/03_20182 017 Statistical_Abstract.pdf. [Accessed: 04 Nov 2019]

2. Shivrath Y, Narayana PB, Thirumalasetty S, Narsaiah EL (2012) Design \& integration of wind-solar hybrid energy system for drip irrigation pumping application. Int J Mod Eng Res 2(4):2947-2950

3. Khan Z, Linares P, García-gonzález J (2017) Integrating water and energy models for policy driven applications. A review of contemporary work and recommendations for future developments. Renew Sust Energ Rev 67:11231138

4. Ronad BF, Jangamshetti SH (2015) Optimal cost analysis of wind-solar hybrid system powered AC and DC irrigation pumps using HOMER. 4th Int Conf Renew Energy Res Appl 5:1038-1042

5. Turyareeba PJ (2001) Renewable energy: its contribution to improved standards of living and modernisation of agriculture in Uganda. Renew Energy 24:453-457

6. Odum HT (1971) Environment, power and society. Wiley-Interscience, New York

7. Bekele G, Tadesse G (2012) Feasibility study of small Hydro/PV/Wind hybrid system for off-grid rural electrification in Ethiopia. Appl Energy 97:5-15

8. Fahmy FH, Ahmed NM, Farghally HM (2012) Optimization of renewable energy power system for small scale brackish reverse osmosis desalination unit and a tourism motel in Egypt. Smart Grid Renew Energy 3:43-50

9. NPHC, "Main report national population and housing census," 2014. [Online]. Available: www.ubos.org. Accessed 4 Nov 2019

10. Chandra D, Singh PK A, Alam T, Bishnoi R, Singh AK 2014. Developing hybrid wind and solar powered irrigation system. Environ. Sustain. Concepts Princ Evidences Innov. pp. 99-105

11. Okou R, Niwagaba E, Kyahingwa O, Edimu M, Sebitosi AB 2013. Considerations for renewable energy mini-grid systems for isolated areas in Uganda. SIDA regional collaboration conference, Bagamoyo, Tanzania

12. NASA, "POWER Data Access Viewer," 2019. [Online]. Available: https://power. larc.nasa.gov/data-access-viewer/. [Accessed: 10 Jul 2019]

13. W. Spark, "Average weather in Kalangala, Uganda, year round - Weather Spark," 2018. [Online]. Available: https://weatherspark.com/y/97220/AverageWeather-in-Kalangala-Uganda-Year-Round. [Accessed: 01 Jun 2018].

14. Johari M, Jalil M, Shariff MM (2018) Comparison of horizontal axis wind turbine (HAWT) and vertical axis wind turbine (VAWT). Int J Eng Technol 7(4. 13):74-80

15. Lasseter RH (2002) "Microgrids," in 2002 IEEE Power Engineering Society Winter Meeting. Conference Proceedings (Cat No 02CH37309) 1:305-308

16. Eid AM, Abdel-Salam M, Abdel-Rahman MT (2006) Vertical-axis wind turbine modeling and performance with axial-flux permanent magnet synchronous generator for battery charging applications. In: 2006 Eleventh International Middle East Power Systems Conference, vol 1, pp 162-166

17. Sinton CW, Butler R, Winnett R (2004) Guide to solar-powered water pumping systems in New York State. NYSERDA

18. Mahindra, "Design of EPC Drip Irrigation System - Mahindra EPC." [Online]. Available: http://www.epcmahindra.com/pdf/how_to_arrive.pdf. Accessed 19 July 2018.

19. Brower C, Heibloem M 1986. Irrigation water management: Irrigation water needs. FAO Training Manual 3. Rome, Italy

20. NAADS, "Banana production guide - National Agricultural Advisory Services," 2019. [Online]. Available: http://www.naads.or.ug/publication/ banana-production-guide/. [Accessed: 06 Jun 2019]

21. Hunter, "Drip irrigation design and installation guide." [Online]. Available: https://www.hunterindustries.com/sites/default/files/dg_plddesignguide_ dom.pdf. [Accessed: 06 Jun 2019]

22. Wu I-P, Gitlin HM (1977) Design of drip irrigation submain. J Irrig Drain Div 103(2):231-243

23. Oğuz Y, Özsoy MF (2015) Sizing, design, and installation of an isolated wind-photovoltaic hybrid power system with battery storage for laboratory general illumination in Afyonkarahisar, Turkey. J Energy South Africa 26(4): 70-80

24. Adejumobi IA, Akinboro FG, Olajide MB (2011) Hybrid solar and wind power: an essential for information communication technology infrastructure and people in rural communities. IJRRAS 9(1):130-138

25. Brusca S, Lanzafame R, Messina M (2014) Design of a vertical-axis wind turbine: how the aspect ratio affects the turbine's performance. Int J Energy Environ Eng 5(4):333-340

26. Bañuelos-Ruedas F, Angeles-Camacho C, Rios-Marcuello S (2011) Methodologies used in the extrapolation of wind speed data at different heights and its impact in the wind energy resource assessment in a region. In: Wind farm-technical regulations, potential estimation and siting assessment, InTech

27. Ochieng PO, Manyonge AW, Oduor AO (2013) Mathematical modelling of power output in a wind energy conversion system. Int J Eng Sci Math 2(4):19

28. Hughes T (2000) "Lesson number 1. In an Oklahoma wind power tutorial series," Univ. Oklahoma 
29. EWEA, "The European Wind Energy Association | EWEA," 2016. [Online]. Available: http://www.ewea.org/. [Accessed: 21 Jul 2018]

30. Wind Watch, "National Wind Watch | Output From Industrial Wind Power," National Wind Watch, Inc. [Online]. Available: https://www.wind-watch.org/ faq-output.php. [Accessed: 21 Jul 2018]

31. Ragheb M (2009) "Optimal rotor tip speed ratio," Available from NetFiles Univ. Illinois Urbana-Champaign, Last Modif

32. Dali M, Belhadj J, Roboam X (2006) Conception et commande de systèmes hybrides photovoltaique-éolien. Rev Int génie électrique 9(6):719-752

33. Blanco Ml (2009) The economics of wind energy. Renew Sust Energ Rev 13(6-7):1372-1382

34. Simmonds NW (1953) The development of the banana fruit. J Exp Bot 4(1): $87-105$

\section{Publisher's Note}

Springer Nature remains neutral with regard to jurisdictional claims in published maps and institutional affiliations.

Ready to submit your research? Choose BMC and benefit from:

- fast, convenient online submission

- thorough peer review by experienced researchers in your field

- rapid publication on acceptance

- support for research data, including large and complex data types

- gold Open Access which fosters wider collaboration and increased citations

- maximum visibility for your research: over $100 \mathrm{M}$ website views per year

At BMC, research is always in progress.

Learn more biomedcentral.com/submissions 